\title{
Impact of tapping quality and harvesting practices on the sustainability of the rubber industry in Sri Lanka
}

\author{
P Seneviratne*, T U K Silva*, K A G B Amaratunga**, \\ R P Karunasena***, R K Samarasekara*, L S Kariyawasam****, \\ M K P Perera*, P D Pathirana* and P K W Karunatilake* \\ * Rubber Research Institute of Sri Lanka, Dartonfield, Agalawatta, Sri Lanka \\ ** 39/5, Hospital Road, Wettawa, Matugama, Sri Lanka \\ *** 25/1, Gamini Mawatha, Matugama, Sri Lanka \\ **** 220/7, New Galle Road, Egodauyana, Moratuwa, Sri Lanka
}

\begin{abstract}
Maintaining the tapping quality in rubber fields is the key requirement to obtain potential yield with minimum harm to the tree. It also determines productivity and the economical lifespan of 30 years and sustainable rubber industry. The length of the tapping cut, the depth, the thickness of the bark shaving, and the slope of the tapping cut are the main factors determining the tapping quality. Use of a stencil according to the intended tapping frequency, i.e. $d 2, d 3, d 4$, etc., to mark the guidelines to maintain the proper tapping angle of 30 degrees to the horizontal, and the bark consumption allowed for one year, are all equally contribute to maintaining the tapping quality. About 5000 ha. was surveyed to assert the tapping quality and to make recommendations. The average bark consumption rate per panel was four years deviating from recommended six years under d2 tapping. The monitory loss per hectare under this bark consumption rate is Rs.2.5 million at a productivity level of $1000 \mathrm{~kg} / \mathrm{ha} / \mathrm{y}$ and Rs.350.00 per $\mathrm{kg}$ of rubber. Trees affected by tapping panel dryness varied and was over $70 \%$ in some extreme cases. Introducing a quarter cut on the upper opposite panel of the tree ceased the situation to a greater extent.
\end{abstract}

Key words: bark audit, excessive bark consumption, harvesting, Hevea, panel dryness, rubber

\section{Introduction}

The extent under rubber cultivation in Sri Lanka has come down from around 200,000 ha. in the 1970s to about 130,000 ha. at present (Anon, 2017). But, the rubber production in Sri Lanka was on an increasing trend until 2016, mainly owing to the usage of high yielding clones and the adoption of improved agro-management practices recommended by the Rubber Research Institute of Sri Lanka. However, from 2016 onward there is a marked decrease in rubber production owing to many reasons such as diversifying rubber lands to other crops mainly oil palm, abandoning productive lands due to low productivity and poor price, etc.

The economical life span of the rubber tree is about 30 years as both the virgin 
and renewed panels are used up in about 24 years under every other day tapping. This can be extended under lowfrequency harvesting. The latex production period of about 24 years can be divided into two phases based on the bark tapped, i.e. virgin bark and renewed bark. The first virgin bark, panel BO- 1 is tapped for 6 years at every other day tapping. The opposite virgin panel, i.e. BO-2, is tapped from 7 to 12 years. The tapping of the first renewed bark, i.e. BI1 should commence from the initial height of the opening of the virgin panel after 12 years and tap from 13 to 18 years. Then the second renewed panel is started from $19^{\text {th }}$ year and at this time quarter upward cuts are opened above the E panel. This is called $150 \%$ intensity and this is gradually increased up to $400 \%$ followed by uprooting the trees for replanting at the end of 24 years of harvesting (Anon, 2016/03).

As far as the clones recommended for planting is concerned, Rubber Research Institute of Sri Lanka has produced the best clones having high yield and important secondary characteristics like disease resistance, high timber volume etc. The clones recommended for planting under Smallholder rubber farmers are in Group I of the recommended list of clones. For the Regional Plantation Companies clones of all three groups I, II, and III along with the newest clones in group IV, as collaborative trials with RRISL, are recommended (Anon, 2013). Among the other unique characteristics such as disease resistance, high timber volume, etc. almost all the clones recommended in the list are capable of giving 2500-
$3000 \mathrm{~kg}$ of rubber per hectare per year. The recommended density of rubber planting at present is 516 trees per hectare, but due to various reasons such as damages due to white root disease incidences, lightning strikes, wind, fire, animal attacks, etc. the tree stand tends to decrease over the years and due to that reason though the bark is available sometimes the clearing becomes uneconomical.

However, in order to harvest the maximum potential yield from any clone or a tree, many factors needed to be fulfilled. Among them, the growth and the physiological condition of the tree, agro management practices, weeding, manuring, branch induction, etc. especially during the immature period, harvesting practices, mainly the frequency and quality, are the most important.

Irrespective of the clone, the growth condition of the tree is important as the vegetative growth or the girth of the tree determines the number of latex vessel rings and thereby the amount of latex that can be harvested from a tree (Nugawela, 2001). Growth which is determined by the growth rate is directly correlated to the quality of the planting material and the maintenance of the clearing during the immature period, mainly the first five years of planting. What is highlighted in this article is the importance of adopting correct harvesting practices in obtaining potential yields from rubber trees.

The tree is tapped for latex once it has reached the tappable girth which is a minimum of $50 \mathrm{~cm}$ girth measured at $120 \mathrm{~cm}$ from the graft union. If a 
P Seneviratne et al.

clearing has more than $70 \%$ of such trees, the clearing becomes tappable and this condition should generally be achieved in 5-6 years of planting. Some Plantation Companies and smallholder farmers tend to postpone the tapping by another year or so and the crop is higher due to higher girth of such trees. Tapping, as described by Ridley in 1889 , is excision of bark without damaging the cambium tissue and is a skilled job. To perform this controlled wounding, a special tool called a tapping knife is used. Mainly two types are used for tapping but in Sri Lanka push knife or the 'Michie Goledge' knife is popular than the pull knife called 'Jebong knife'. The bark consumption is generally higher with the Jebong knife.

The ideal harvesting method is expected to cause the least damage while giving out the potential yield of the tree at the lowest possible cost. Accordingly, an ideal harvesting method should remove only about $1 / 20 "(1.25 \mathrm{~mm})$ thick bark shaving, cut open as many latex vessels as possible without damaging the cambium while maintaining the correct angle of 30 degrees to the horizontal and marked from high right to low left. A slope of a few degrees should also be maintained on the tapping cut towards the tree to prevent latex spillage. Marking 'Neththi Kanu' and 'Poi Kanu' by correctly dividing the tree into two halves with the use of a measuring tape and use of a stencil according to the intended tapping frequency, i.e. $\mathrm{d} 2$ or $\mathrm{d} 3$ are important practices. Even if the stencil is used if it is not properly placed on the tree, the angle of 30 degrees cannot be achieved. Therefore, the correct angle and the guidelines for the tapper on bark consumptions allowed per quarter should be marked annually to control bark consumption. Therefore, a new clone is generally released along with a harvesting method, especially the harvesting frequency. This is more important for high yielding clones as if a high yielding clone is harvested at a higher frequency than the recommended, trees become very stressed and eventually dry within a short period of about 6-12 months (Eschbach et al., 1989). This condition is generally termed as "brown bast" or tapping panel dryness where the bark is live but latex vessels are dry. Tapping panel dryness is observed in almost every rubber clearing but in an accepted level and generally an increase is observed with the advancement of the panels from BO-1 to BI-2. During the first 5-6 years of tapping, only about 5\% tapping panel dryness is generally accepted. The quality of tapping and the tapping frequency determine the productivity and the productive lifespan of rubber cultivations. Low yielding clones planted early days could withstand daily tapping but the high yielding clones that are planted at present should be tapped every other day, i.e. $\mathrm{d} 2$ frequency and some clones once in every three days, i.e. $\mathrm{d} 3$ frequency.

The main objective of the survey conducted was a proper bark auditing on tapping quality and field wise remedial measures to arrest the condition of poor intakes and high brown bast incidences. 
Impact of tapping quality on sustainability of rubber

\section{Methodology}

Based on the information received from Regional Plantation Companies (RPCs) in 2009 on poor yields, poor intake per tapper, and a high number of dry trees in rubber fields, the survey was carried out during the year 2010 covering all RPCs having rubber estates. To schedule the field visits, information on estates, divisions, fields, extents, age, and years under tapping were collected in advance through emails. Fields tapped on D panel were excluded in many occasions. As the general norm of tapping is 300 trees, data collection was done in about $10 \%$ of the trees representing each field. Blocks were selected to represent each tapper and at least 30 trees were selected in a Zig-Zag pattern across the field and in some cases every $11^{\text {th }}$ tree was used to collect data. The format used to collect data contained, name of the estate, division, extent, year of planting the field, year of opening for tapping, clones planted, number of tapping blocks, opening height of tapping, tapping system, estate representation and date of inspection. To calculate the bark consumption rate, the actual panel position was measured with a measuring tape and the number of years in tapping was recorded from their records available at the Estate Office.

For the tapping quality, angle of tapping, angle of the cut, depth of tapping, bark consumption, and length of the cut was recorded for 30 trees per block and percentage correctness was calculated.
Estimation of percentage correct tapping angle

$\% C A=\frac{T C}{m} X 100$

where, " $T C$ " is the number of trees with correct tapping angle and " $m$ "is the total inspected trees in the tapping block. Then, percentage of trees with correct tapping angle of a clearing $\left(\% C A_{c}\right)$ was estimated as,

$$
\% C A_{c}=\frac{\sum_{i=1}^{n} \% C A_{i}}{n}
$$

where, $\% C A_{i}$ is the percentage correct tapping angle in the $i^{\text {th }}$ block of the clearing and " $n$ " is the total number of tapping blocks in the clearing.

\section{Estimation of percentage correct tapping depth}

Percentage of trees with correct tapping depth of a tapping block ( $\% C D)$ was estimated as.

$\% C D=\frac{T D}{m} X 100$

Where, TD is the No. of trees with correct tapping depth in the tapping block and " $m$ " is the total inspected trees in the tapping block. Then, the percentage of trees with correct tapping depth of a clearing was calculated as,

$$
{ }_{0} C D_{c}=\frac{\sum_{i=1}^{n} \% C D_{i}}{n}
$$

where, $\% C D_{i}$ is the percentage of trees with correct tapping depth in the $\mathrm{i}^{\text {th }}$ block of the clearing and the " $n$ " is the number of blocks in the clearing. 


\section{Estimation of correct tapping length}

Percentage of trees with correct tapping length of a tapping block $(\% C L)$ was estimated as,

$\% C L=\frac{T L}{m} X 100$

Where, "TL" is the no. of trees with correct tapping depth in the tapping block and " $m$ " is the total inspected trees in the tapping block. Then, the percentage of trees with correct tapping depth $\left(\% \mathrm{CL}_{\mathrm{c}}\right)$ of a clearing was calculated as,

$$
\% C L_{c}=\frac{\sum_{i=1}^{n} \% C L_{i}}{n}
$$

where, $\% C L_{i}$ is the percentage of trees with correct tapping depth in the $\mathrm{i}^{\text {th }}$ block of the clearing and the $n$ is the number of blocks in the clearing.

\section{Estimation of bark consumption}

With the data collected, the correct panel was estimated and then the total excessive bark consumption, excessive bark consumption per year and the life span of each A, B, C and D panels were calculated as follows.

Let bark consumption of a tapping block $(B C)$ is defined as

$$
B C=\frac{\sum_{\boldsymbol{j}=\mathbf{1}}^{\boldsymbol{m}} \boldsymbol{h}_{\boldsymbol{j}}}{\boldsymbol{m}}
$$

where" $\boldsymbol{h}_{\boldsymbol{j}}$ " is the bark consumption of $\boldsymbol{j}^{\text {th }}$ tree in the tapping block and " $m$ " is the total number of tree in the tapping block. Then the bark consumption of a clearing $\left(B C_{C}\right)$ was estimated as

$$
B C_{c}=\frac{\sum_{\boldsymbol{i = 1}}^{\boldsymbol{n}} \boldsymbol{B} \boldsymbol{C}_{\boldsymbol{i}}}{\boldsymbol{n}}
$$

where $B C_{i}$ is the bark consumption of $\mathrm{i}^{\text {th }}$ tapping block and" $\boldsymbol{n}$ " is the number of tapping blocks in the clearing. Using calculated " $B C_{c}$ " and total duration under tappingin years of the clearing (T), annual bark consumption $\left[A B C\left(c m y^{-1}\right)\right]$ was estimated using the following formula.

$$
A B C\left(c m y^{-1}\right)=\frac{B C_{c}}{T}
$$

The life span of a tapping panel of a given clearing $\left(\operatorname{LoTP}_{C}\right)$ can be estimated using the following formula.

$$
\operatorname{LoTP}_{c}=\frac{H}{A B C}
$$

where, $\mathrm{H}$ is the opening height of the panel.

In order to calculate the percentage of trees with dry panels, a count of dry trees was taken. Determining the dry trees is difficult as it happens gradually over a period of time. When the yield was very poor they were considered as dry in this study.

About 5000 ha. under the regional plantation companies were assessed to collect data. Only the fields that were tapped at $\mathrm{S} / 2 \mathrm{~d} 2$ system were selected initially. The clones represented were mainly RRIC 121, RRIC 100 and RRIC 102.

Simultaneously, all Field Officers of the estates, Rubber Development Officers of the Rubber Development Department and the Rubber Extension Officers of the RRISL were trained at the RRISL by the Officers of RRISL on bark auditing. Training was done on every Tuesday for a period of about six months and around 600-700 people were trained. 
Impact of tapping quality on sustainability of rubber

The Regional Plantation Companies and rubber estates, where the survey was carried out are presented in Table 1.

\section{Results}

Though the list of estates was given in the methodology, the identity of the estates was confidential and therefore, estates are identified as 1, 2, 3, etc. without divulging the names of the estates.

Table 1. The Regional Plantation Companies and rubber estates, where the survey was carried out

\begin{tabular}{|c|c|}
\hline Plantation Company & Estate \\
\hline 1. Pussellawa & $\begin{array}{l}\text { Pussella } \\
\text { Pambegama } \\
\text { Penrith } \\
\text { Siriniwasa } \\
\text { Salawa } \\
\text { Halpe } \\
\text { Sunderland } \\
\text { Durampitiya } \\
\text { Eheliyagoda } \\
\text { Elston } \\
\text { Ayr }\end{array}$ \\
\hline 2. Kelanivalley & $\begin{array}{l}\text { Dewalakanda } \\
\text { Ganepalla } \\
\text { Lavent } \\
\text { Urumeewala } \\
\text { Panawatta } \\
\text { Kiriporuwa } \\
\text { Edarapola } \\
\text { Kelani } \\
\text { Weoya } \\
\text { Kalupahana }\end{array}$ \\
\hline 3. Agalawatta & $\begin{array}{l}\text { Ambetenna } \\
\text { Clyde } \\
\text { Culloden } \\
\text { Doloswella } \\
\text { Kiribathgala } \\
\text { Kiriwanaketiya } \\
\text { Mohomedi } \\
\text { Niriella } \\
\text { Niriwatta } \\
\text { Noragalla } \\
\text { Peenkande } \\
\text { Pimbura } \\
\text { Watapotha }\end{array}$ \\
\hline
\end{tabular}

\begin{tabular}{ll}
\hline Plantation Company & Estate \\
\hline 4. Horana & Neuchatel \\
& Hillstream \\
& Mirishena \\
& Halwathura \\
& Dumbara \\
\hline 5. Kotagala & Eduragala \\
& Delkeith \\
& Padukka \\
\hline 6. Balangoda & Millawitiya \\
& Mahawela \\
& Galathura \\
& Palmgarden \\
& Rambukkanda \\
& Matuwagala \\
\hline 7. Lalan & Udabage \\
\hline 8. Kahawatta & Ekkerella \\
& Houpe \\
& Hunuwella \\
& Opatha \\
& Pelmadulla \\
& Poronuwa \\
& Rilhena \\
& Wellandura \\
\hline 8. Katawala & Nakiyadeniya \\
& Homadola \\
& Thalangaha \\
\hline & Atale \\
\hline
\end{tabular}

Tapping quality

The results indicated that the percentage of correct adoption has deviated from the recommended criteria in most of the 
cases. The percentage of $100 \%$ adoption, $100 \%$ deviation, and the average adoption rate for each criterion, the angle of tapping, the depth of tapping, and the length of the tapping cut are given in Table 2.

The reasons for the results given in the Table 2, on common errors are shown in Fig. 1a, b, c, and d.

Table 2. The percentage of $100 \%$ adoption, $100 \%$ deviation, and the average adoption rate for each criterion, the angle of tapping, the depth of tapping, and the length of the tapping cut

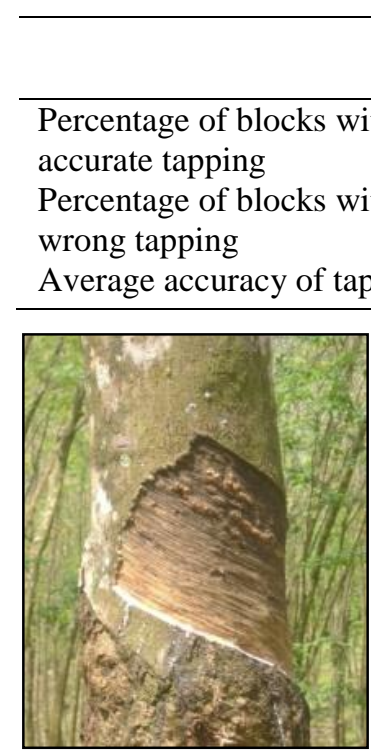

(a)

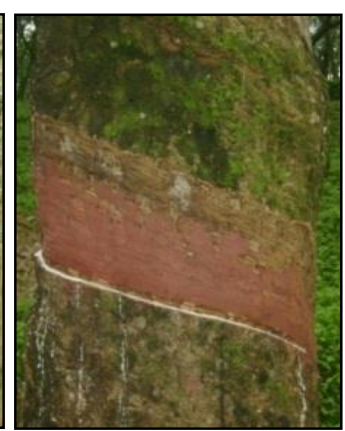

(b)

\section{Angle of} tapping (\%)

4.57

6.2 46.85

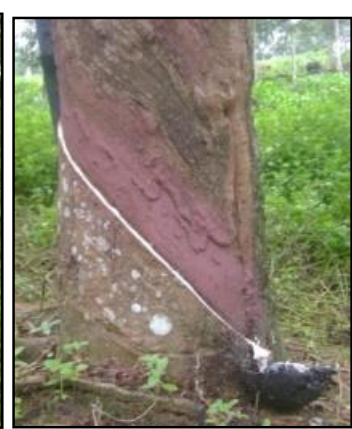

(c)

Depth of tapping (\%)

20

6.2

54.16

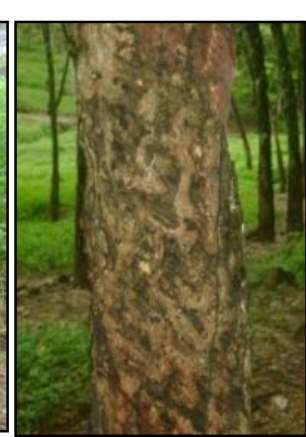

(d)

Length of $\frac{\text { tapping cut }(\%)}{38.28}$

Fig. 1. (a). No marking of 'Poi Kanu' or 'Neththi' kanu' and thereby indiscriminate use of panels. The base panels have totally been consumed and the current panel is marked above the base panels and again downward tapping is done on the higher panels and minimum yield is obtained.

(b). Incorrect angle of less than 30 degrees which has resulted very low yields due to coagulation of latex on the cut due to slow latex flow.

(c). Angle of more than 30 degrees which leads to wasting of a bigger potion of panel along with other disadvantages.

(d). Nodule formation on the renewed panel due to poor tapping done on the virgin panel.

\section{Bark consumption}

Data collected on bark consumption and the bark consumption rate showed that they have exceeded the recommended rate of frequency of tapping in almost every clearing, irrespective to the panel.
Data on year of planting, age of the clearing, year of commencement of tapping, number of years in tapping, current panel in tapping, expected panel and remarks for all the fields of one estate belongs to one of the RPCs are 
Impact of tapping quality on sustainability of rubber

given in Table 3. As it is clear from the data of Table 3, the age of the clearings varies from 15 to 27 years and none of the clearings have any bark left on the trees to harvest any crop. Though this was an extreme case, there were fields of this kind in other estates too.
Average values of actual and recommended bark consumption for nine estates of Plantation Company 1 are given in Figure 2a. As it is clear from the Figure 2a, the actual bark consumption is higher than the recommended or the estimated bark consumption.

Table 3. Year of planting, age of the clearing, year of commencement of tapping, number of years in tapping, expected panel, actual panel in tapping, and remarks for the clearings in one of the estates surveyed

\begin{tabular}{lllllll}
\hline & & & & \\
& & & & & \\
1985 & 27 & 1991 & 21 & $\mathrm{D} 3$ & No bark (400\%) & Highly intensified (no bark) \\
1986 & 26 & 1992 & 20 & $\mathrm{D} 2$ & No bark (400\%) & Highly intensified (no bark) \\
1987 & 25 & 1993 & 19 & $\mathrm{D} 1$ & No bark (400\%) & Highly intensified (no bark) \\
1988 & 24 & 1994 & 18 & $\mathrm{C} 6$ & $\mathrm{No}$ bark (400\%) & Highly intensified (no bark) \\
1989 & 23 & 1995 & 17 & $\mathrm{C} 5$ & $\mathrm{No}$ bark (400\%) & Highly intensified (no bark) \\
1990 & 22 & 1996 & 16 & $\mathrm{C} 4$ & $\mathrm{No}$ bark (400\%) & Highly intensified (no bark) \\
1991 & 21 & 1997 & 15 & $\mathrm{C} 3$ & $\mathrm{D}(400 \%)$ & Highly intensified (no bark) \\
1993 & 19 & 1999 & 13 & $\mathrm{C} 1$ & $\mathrm{D}(400 \%)$ & Highly intensified (no bark) \\
1994 & 18 & 2000 & 12 & $\mathrm{~B} 6$ & $\mathrm{D}(400 \%)$ & Highly intensified (no bark) \\
1995 & 17 & 2001 & 11 & $\mathrm{~B} 5$ & $\mathrm{D}(200 \%)$ & Highly intensified (no bark) \\
1996 & 16 & 2002 & 10 & $\mathrm{~B} 4$ & $\mathrm{D}(400 \%)$ & Highly intensified (no bark) \\
1997 & 15 & 2003 & 9 & $\mathrm{~B} 3$ & $\mathrm{D}(400 \%)$ & Highly intensified (no bark) \\
\hline
\end{tabular}

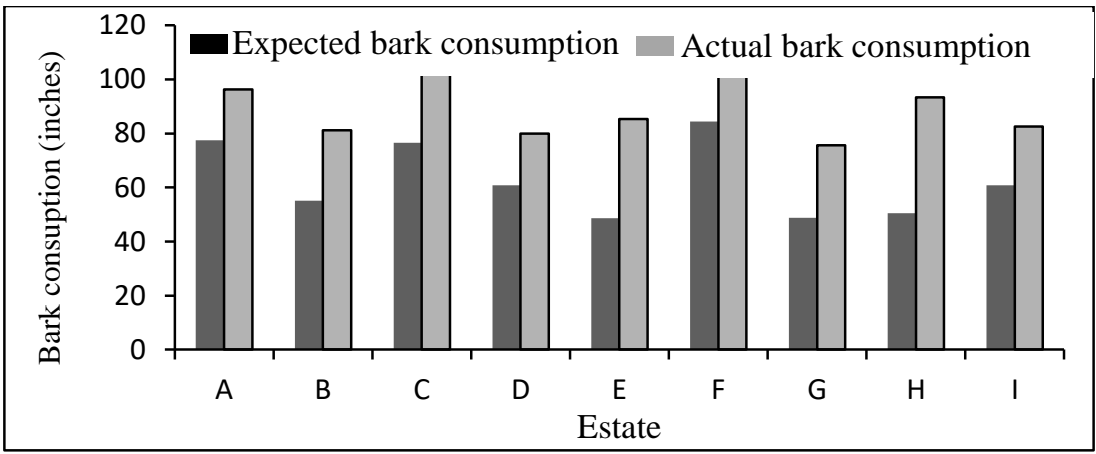

Fig. 2a. Average values of expected and actual bark consumption for nine estates of Plantation Company 1. 
P Seneviratne et al.

Percentage of the excess consumption calculated for all fields with compared to the recommended panel position for the same estates of Plantation Company 1 is shown in Figure $2 \mathrm{~b}$. The percentage values vary from about $18 \%$ to $85 \%$ among the estates as seen from Figure 1b. The actual and recommended bark consumption for eight estates of
Plantation Company 2 are given in Figure 3a.

Percentage of the excess consumption with compared to the recommended panel position for the Plantation Company 2 is shown in Figure 3b. A variation from $40 \%$ to $110 \%$ bark consumption is seen the estates under Plantation Company 2.

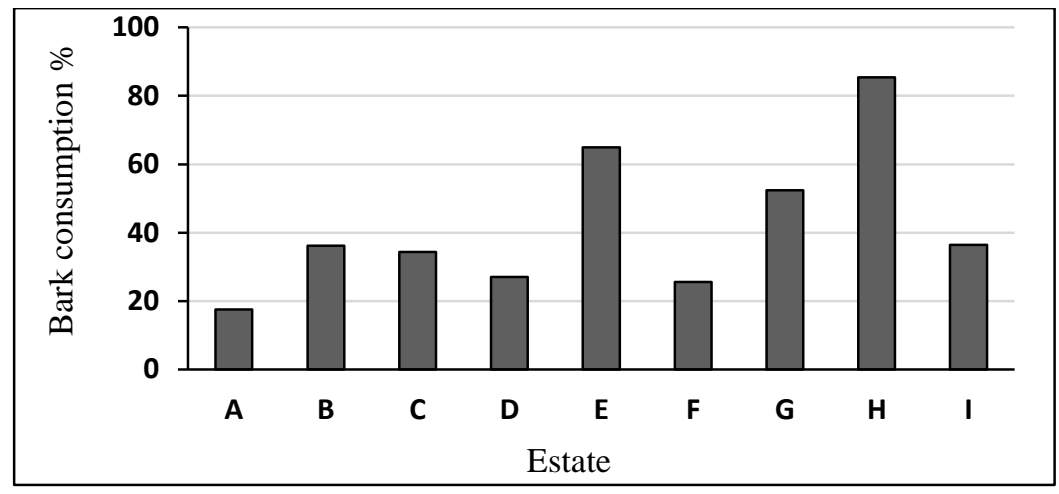

Fig. 2b. Percentage of the excess consumption with compared to the recommended panel position for the nine estates of the Plantation Company 1

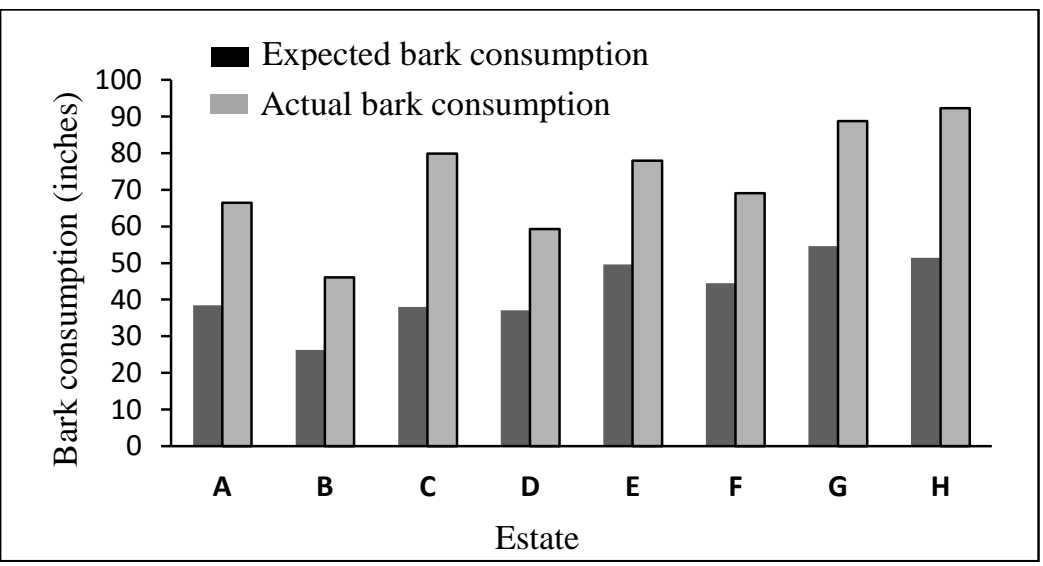

Fig. 3a. The expected and actual bark consumption for eight estates of Plantation Company 2 


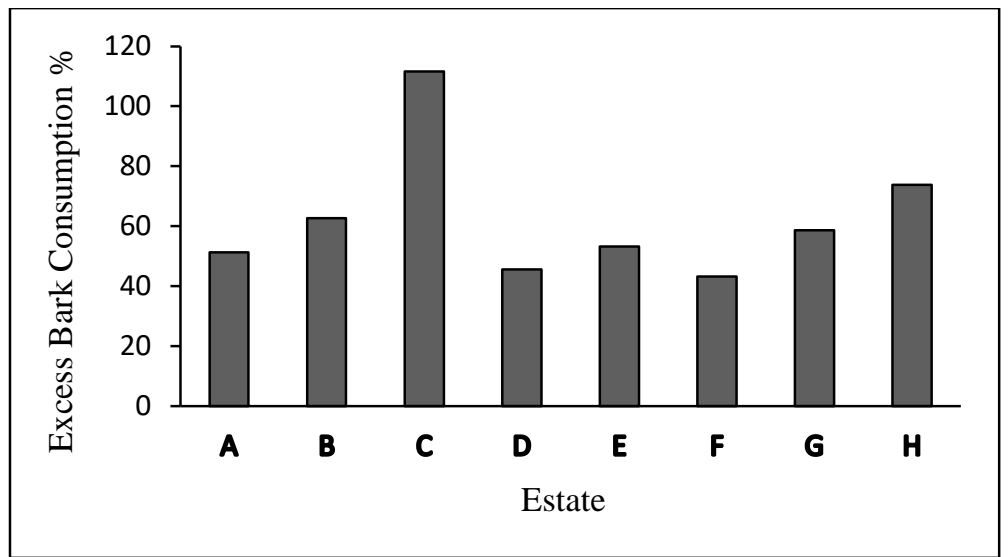

Fig. 3b. Percentage of the excess consumption with compared to the recommended panel position for the eight estates of Plantation Company 2

The actual and recommended bark consumption for estates of Plantation Company 3 are given in Figure $4 \mathrm{a}$. Percentage of the excess consumption with compared to the recommended panel position for the Plantation Company 3 is shown in Figure 4b. The percentage vary from $30 \%$ to $80 \%$ among the estates.

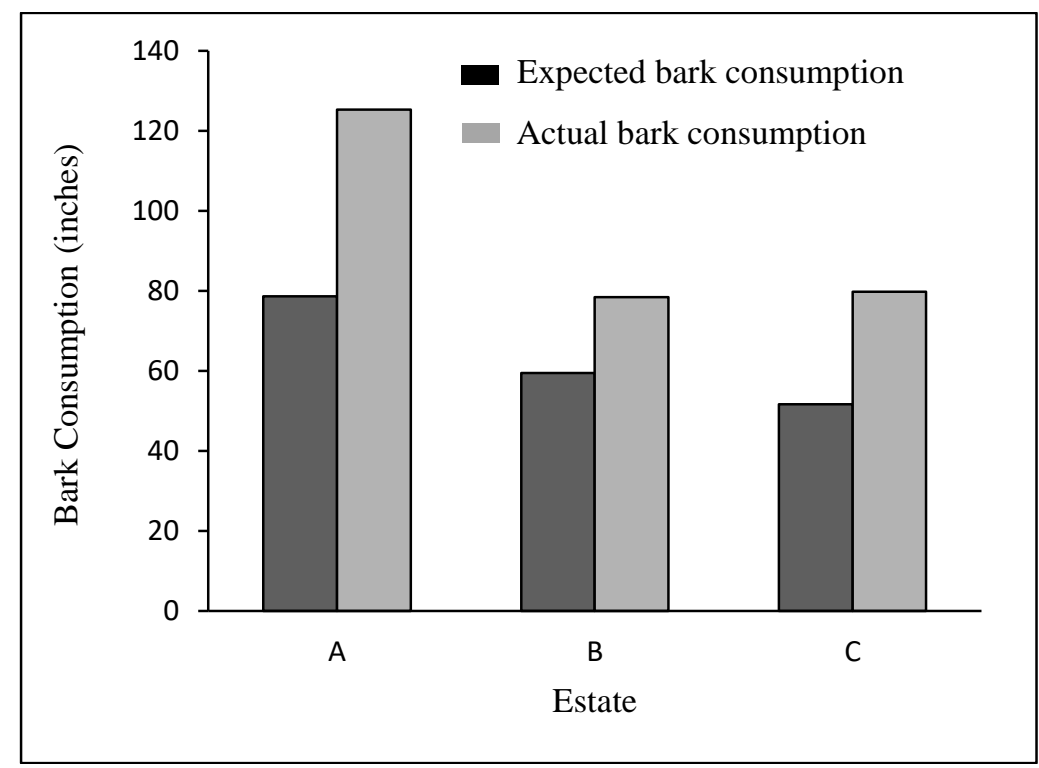

Fig. 4a. The expected and actual bark consumption for the three estates of Plantation Company 3 


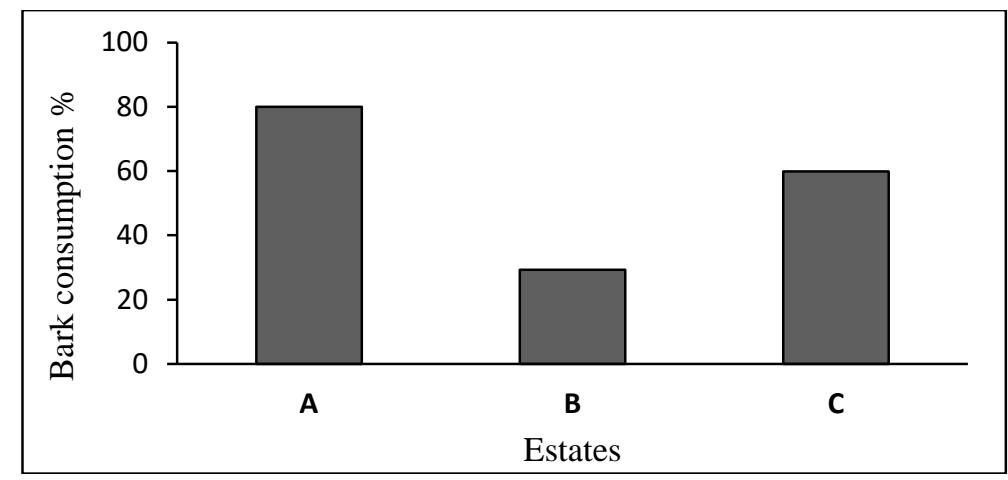

Fig. 4b. Percentage of the excess consumption with compared to the recommended panel position for the Plantation Company 3

Bark consumption was always higher in all the estates and therefore results for individual estates or plantation companies were not discussed in this paper. But detailed reports were provided for each estate.

The summary of the average life span of the two virgin panels, $\mathrm{A}$ and $\mathrm{B}$, for all fields of all the estates as per the rate adopted is shown in Figure 5. For this figure, data collected from about 5000 ha. representing many RPCs and estates have been used and therefore is considered a reliable information representing the entire sector. As the expected lifespan of two virgin panels under $\mathrm{d} 2$ tapping is 12 years, only about $15 \%$ of the extent is within that as per the Figure 4 . About $5 \%$ of the area shows less than 5-6 years for panels A and B. Also an area close to $60 \%$ has consumed the two virgin panels in less than nine years and it was an alarming situation.

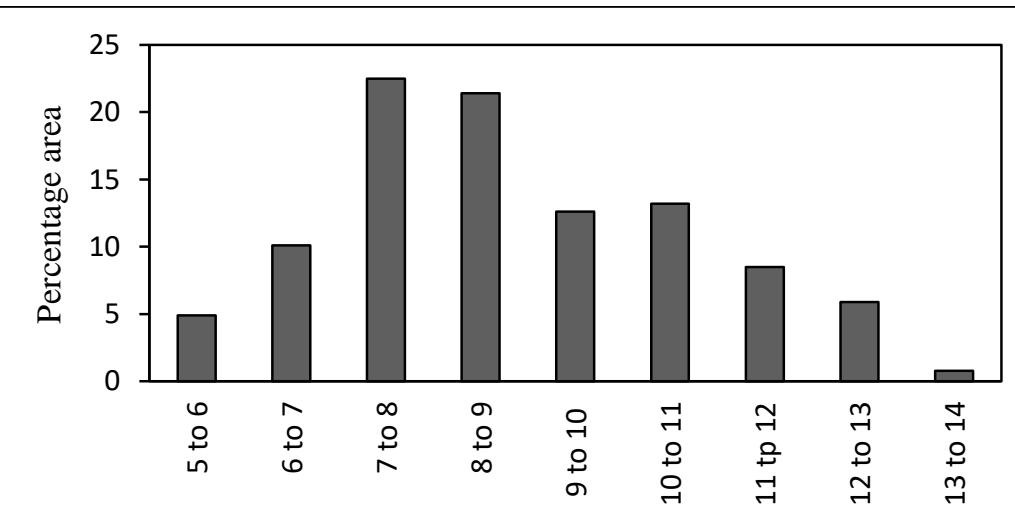

Life span of A and B panels (years)

Fig. 5. The summary of the average life span of the panels of all fields of all the estates as per the rate adopted 
The age wise distribution of expected and actual panel positions for all the fields in one estate were calculated to see any correlation between the age of the clearing and the bark consumption. Actual panel position and the expected panel positions for all fields in one estate are shown in Figure 6. Percentage of bark consumption indicates high variation among fields, some exceeding $100 \%$, but no correlation was seen and young clearings too showed very high excessive bark consumption.

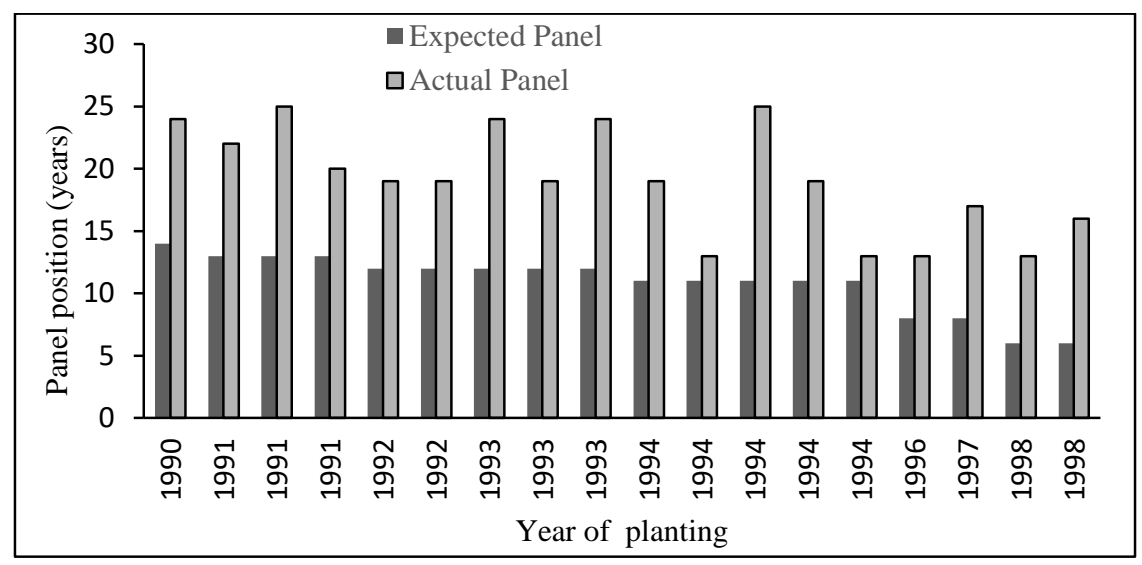

Fig. 6. Actual panel positions and the expected panel positions for all fields in one estate

However, according to some of the managers of RPCs, the excessive bark consumption was partly due to the unskilled tappers. It can be true to a certain extent but, many tappers had performed so well during the bark audit, and could remove a shaving of $1.25 \mathrm{~mm}$ or less, without causing any damage to the tree. Figure 7 shows a rare incident of very thick shavings and estates are generally very attentive on such tappers. It is a general practice of the tappers to remove a thicker bark shaving after many absent tapping days.

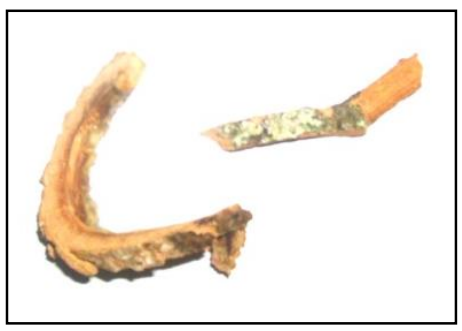

Fig. 7. A very thick bark shaving of about $5 \mathrm{~mm}$

\section{Tapping Panel Dryness}

The brown bast or the condition of tapping panel dryness (TPD) of the fields in one of the estates belongs to one of the RPCs surveyed is shown in Figure 8. Though there is no clear pattern 
P Seneviratne et al.

between the percentage of TPD trees and the age of the field, the three fields on panel BO-1 or the first virgin panel shows no trees with tapping panel dryness. However, the fields have been in tapping only for 1-3 years when data were collected.

A correlation could be seen between the age and the bark consumption of the fields of an estate and the recommended and the actual bark consumption of all fields of this estate in Kaluthara region is given in Figure 9a. The percentage of excessive bark consumption of fields are given in Figure 9b. The percentage of brown bast or tapping panel dryness incidences for the area shown in Figure 9c.

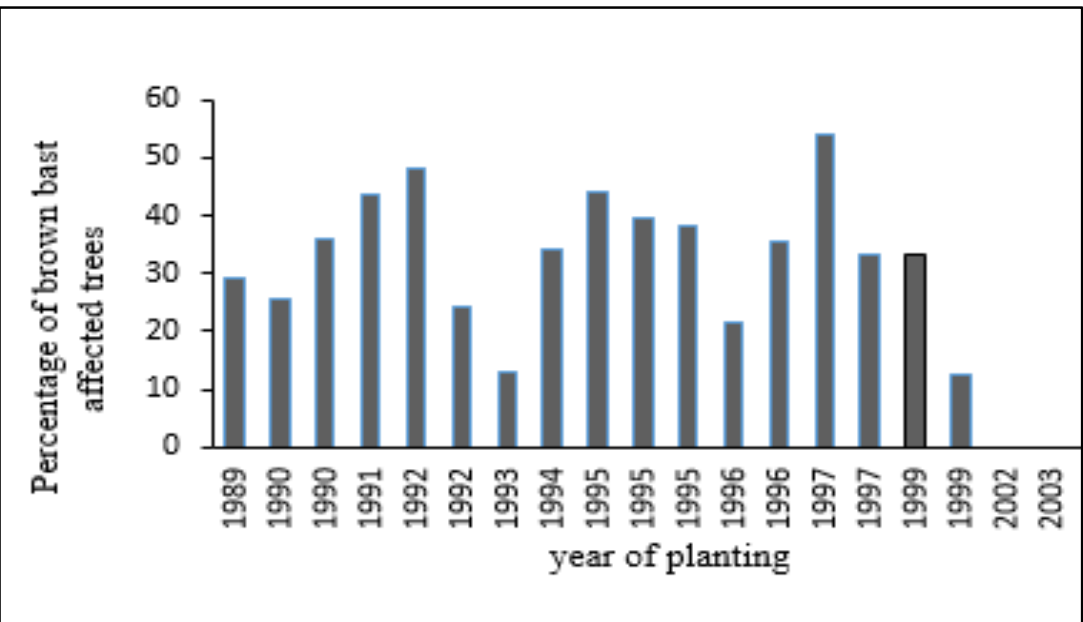

Fig. 8. The percentage of brown bast condition of the fields in one of the estates belongs to one of the RPCs

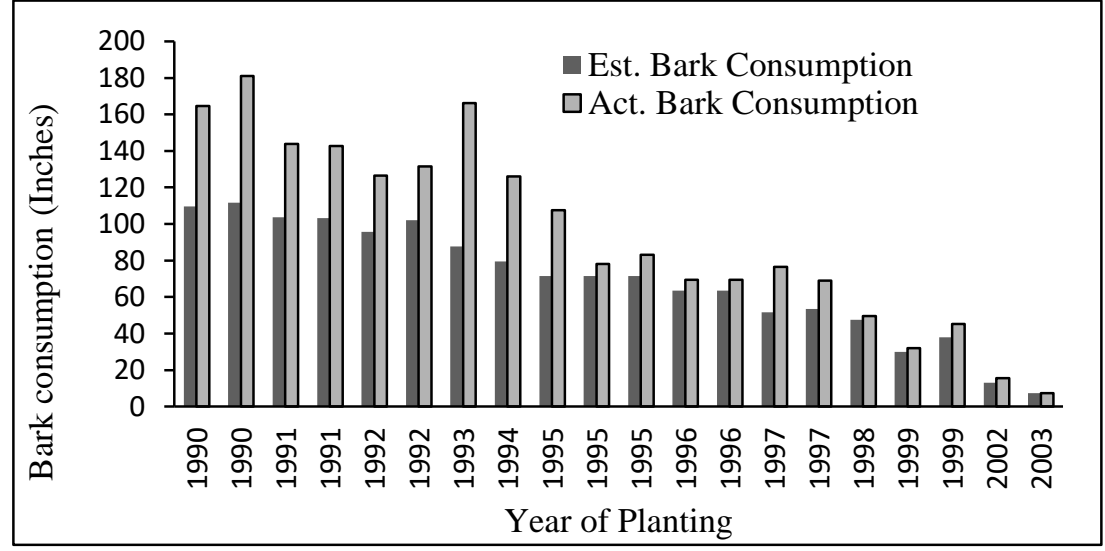

Fig. 9a. The recommended and the actual bark consumption of all fields in one estate in the Kaluthara region 


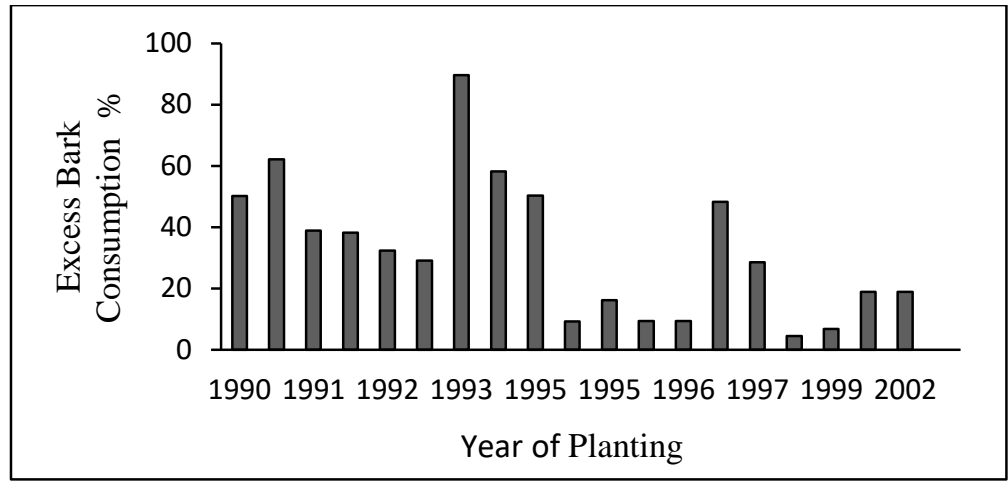

Fig. 9b. The percentage of excess bark consumption of the same fields

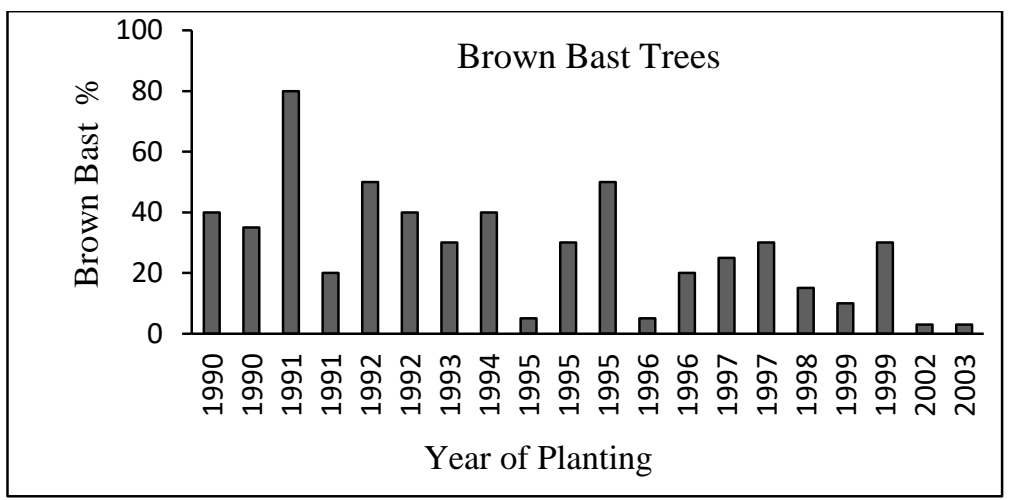

Fig. 9c. The percentage of brown bast (BB\%) incidences for the same fields

The correlation between the excess bark consumption and the tapping panel dryness for the fields of this particular estate is shown in Figure 10.

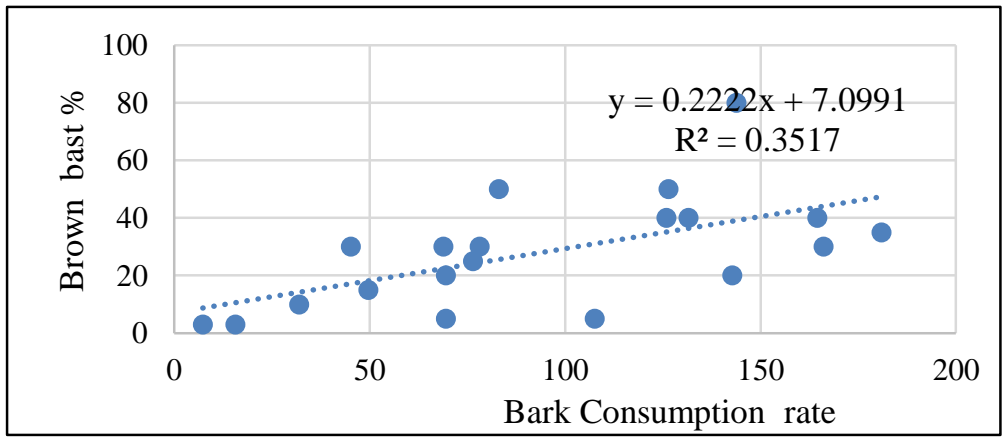

Fig. 10. Correlation between the bark consumption rate and the tapping panel dryness in the tapping fields in the particular estate shown in Figures 9a, b and c 
P Seneviratne et al.

The year of planting, year and extent audited, estimated and actual panel position and the tapping quality of the estates audited from 2013 to 2020 are given in Table 4. It is clear from the data, the gap between the actual and the estimated panel positions vary from field to field. Also, it is clear when the taping quality is very good or good, the gap between the estimated and the actual panel positions are lower when compared to gap where the tapping quality is poor and very poor.

Table 4. The year of planting, year audited, extent audited, estimated panel position, actual panel position and the tapping quality of the estates audited from 2013 to 2020

\begin{tabular}{|c|c|c|c|c|c|}
\hline $\begin{array}{l}\text { Year of } \\
\text { planting }\end{array}$ & $\begin{array}{l}\text { Year } \\
\text { audited }\end{array}$ & $\begin{array}{l}\text { Extent } \\
\text { audited (ha.) }\end{array}$ & $\begin{array}{l}\text { Estimated } \\
\text { panel position }\end{array}$ & $\begin{array}{l}\text { Actual } \\
\text { panel } \\
\text { position }\end{array}$ & $\begin{array}{l}\text { Tapping } \\
\text { quality }\end{array}$ \\
\hline 1989 & 2013 & 7.8 & $\mathrm{C} 5$ & C\&D & ++++ \\
\hline 1989 & 2013 & 2.7 & $\mathrm{C} 1$ & $\mathrm{~B} 6+\mathrm{C}$ & +++++ \\
\hline 1989 & 2013 & 4.1 & C3 & $\mathrm{B}+\mathrm{C}$ & +++++ \\
\hline 1989 & 2013 & 9.1 & C3 & $\mathrm{D}$ & ++ \\
\hline 1989 & 2013 & 3.0 & C6 & D2 & ++ \\
\hline 2007 & 2013 & 4.5 & A4 & B2 & + \\
\hline 2007 & 2013 & 6.1 & A6 & B6 & + \\
\hline 1999 & 2013 & 6 & B1 & $\mathrm{C} 4$ & + \\
\hline 1999 & 2013 & 2 & B2 & D2 & + \\
\hline 1999 & 2013 & 2.3 & $\mathrm{~B} 2$ & $\mathrm{D}$ & + \\
\hline 2007 & 2016 & 6.42 & A3 & $\mathrm{A} 3$ \& A4 & +++++ \\
\hline 2006 & 2016 & 11.6 & A5 & A5 \& A6 & +++++ \\
\hline 2004 & 2016 & 10.6 & A7 & B1 & ++++ \\
\hline 2008 & 2016 & 1.22 & $\mathrm{~A} 2$ & $\mathrm{~A} 2 \& \mathrm{~A} 3$ & +++++ \\
\hline 1988 & 2016 & 11.46 & $\mathrm{D}$ & Not clear & + \\
\hline 1981 & 2016 & 4.51 & D2 & Not clear & + \\
\hline 1989 & 2016 & 4.1 & $\mathrm{D}$ & Not clear & + \\
\hline 1987 & 2016 & 9.47 & $\mathrm{D}$ & Not clear & + \\
\hline 1999 & 2016 & 5.64 & B4 & Not clear & + \\
\hline 1999 & 2016 & 12.78 & B3 & B8 & ++ \\
\hline 1994 & 2017 & 7.1 & $\mathrm{C}$ & $E \& F$ & + \\
\hline 1995 & 2017 & 13.1 & $\mathrm{C}$ & $E \& F$ & + \\
\hline 1996 & 2017 & 5.1 & $\mathrm{C}$ & $D \& E$ & + \\
\hline 1997 & 2017 & 12 & $\mathrm{C}$ & $D \& E$ & + \\
\hline 1997 & 2017 & 4 & $\mathrm{C}$ & $\mathrm{D} \& \mathrm{E}$ & + \\
\hline 2000 & 2017 & 1 & B & $\mathrm{C}, \mathrm{D} \& \mathrm{E}$ & + \\
\hline 2003 & 2017 & 9.0 & B & $C \& D$ & + \\
\hline 2004 & 2017 & 7 & $\mathrm{~A}$ & B & + \\
\hline 2005 & 2017 & 6.9 & A7 & B4 & + \\
\hline 2006 & 2017 & 7.6 & A6 & B1 & ++ \\
\hline 1984 & 2018 & 5 & $\mathrm{C} 2$ & $\mathrm{D}$ & + \\
\hline
\end{tabular}


Impact of tapping quality on sustainability of rubber

\begin{tabular}{|c|c|c|c|c|c|}
\hline $\begin{array}{l}\text { Year of } \\
\text { planting }\end{array}$ & $\begin{array}{l}\text { Year } \\
\text { audited }\end{array}$ & $\begin{array}{l}\text { Extent } \\
\text { audited (ha.) }\end{array}$ & $\begin{array}{l}\text { Estimated } \\
\text { panel position }\end{array}$ & $\begin{array}{l}\text { Actual } \\
\text { panel } \\
\text { position }\end{array}$ & $\begin{array}{l}\text { Tapping } \\
\text { quality }\end{array}$ \\
\hline 2004 & 2018 & 20 & B1 & B4 & ++ \\
\hline 2005 & 2018 & 30 & A6 & B6 & + \\
\hline 2006 & 2018 & 30 & A5 & B6 & + \\
\hline 2007 & 2018 & 29 & A5 & $A \& B$ & ++ \\
\hline 2009 & 2018 & 2 & $\mathrm{C} 4$ & $\mathrm{E}$ & + \\
\hline 2000 & 2018 & 1.3 & $\mathrm{C} 1$ & D4 & + \\
\hline 2000 & 2018 & 5 & $\mathrm{C} 1$ & $\mathrm{D}$ & + \\
\hline 2008 & 2018 & 10 & $\mathrm{C} 4$ & D\&E & + \\
\hline 2008 & 2018 & 6 & $\mathrm{C} 3$ & $\mathrm{E}$ & + \\
\hline 2008 & 2019 & 3.2 & $\mathrm{C} 4$ & D\&E & + \\
\hline 1989 & 2019 & 4.6 & $\mathrm{C} 2$ & D\&E & + \\
\hline 2001 & 2019 & 5 & B4 & $\mathrm{C}$ & ++ \\
\hline 2008 & 2019 & 11.9 & B3 & B & ++++ \\
\hline 1999 & 2019 & 15.8 & B2 & $\mathrm{C}$ & ++ \\
\hline 1989 & 2019 & 2 & $\mathrm{C} 2$ & D\&E & + \\
\hline 1988 & 2019 & 6 & $\mathrm{C} 3$ & D\&E & + \\
\hline 1988 & 2019 & 10.8 & $\mathrm{C} 3$ & D\&E & + \\
\hline 1989 & 2019 & 6.8 & $\mathrm{C} 2$ & D\&E & + \\
\hline 2007 & 2019 & 10 & A3 & A4 & ++++ \\
\hline 1989 & 2020 & 5 & $\mathrm{C} 2$ & $\mathrm{D}$ & + \\
\hline 1989 & 2020 & 8 & $\mathrm{C} 3$ & $\mathrm{D}$ & + \\
\hline 2008 & 2020 & 4.6 & C6 & $\mathrm{D}$ & + \\
\hline 2009 & 2020 & 5.6 & $\mathrm{C} 4$ & $\mathrm{D}$ & + \\
\hline 2008 & 2020 & 14.4 & $\mathrm{C} 4$ & $\mathrm{D}$ & + \\
\hline 2001 & 2020 & 5.9 & B6 & C6 & + \\
\hline 2008 & 2020 & 7 & $\mathrm{C} 4$ & $\mathrm{D}$ & + \\
\hline 1989 & 2020 & 4.3 & $\mathrm{C} 3$ & $\mathrm{D}$ & + \\
\hline 1989 & 2020 & 6.3 & $\mathrm{C} 4$ & $\mathrm{D}$ & + \\
\hline 1988 & 2020 & 5 & $\mathrm{D}$ & $\mathrm{D}$ & + \\
\hline
\end{tabular}

\section{Ad hoc tapping practices}

The general practice adopted in many estates when the tapping panel dries partially or fully was to switch over to the opposite panel. However, various kinds of ad hoc tapping were seen, and the tappers' explanation was most of the time was to avoid dry areas of the tapping cut (Figs. 11a and b). Tapping quality, as it is seen in Figures 10a and b is also very poor and nodule formation is very high. 
P Seneviratne et al.

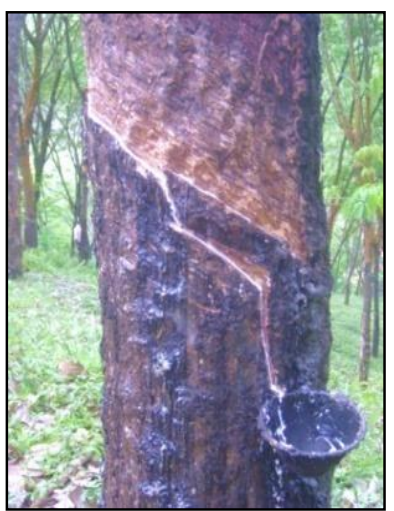

(a)

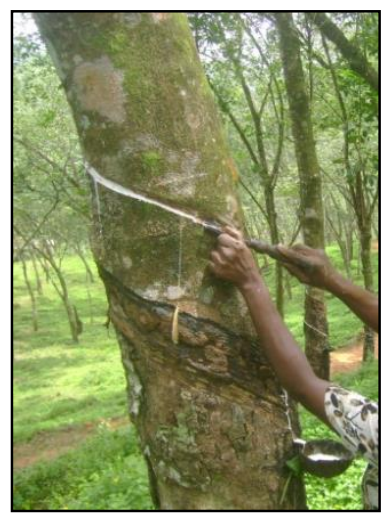

(b)

Fig. 11. (a). Changing the tapping cut in order to avoid the dry areas and (b). a new cut opened above the base panel due to drying up of the original base panel

\section{Discussion}

Though harvesting is the most important agro management practice on an estate, so many malpractices are seen including tapping of under-girth-trees which are not reported in the results. The main concern throughout the survey was to stop immediately the excessive bark consumption rate which was far too high and if continued would totally ruin the rubber industry. However, the approach was timely, correct and straight forward which resulted the expected outcome in almost all the estates. While giving the required recommendations, all the field staff and the management were clearly educated on the situation and convincing was easy due high brown bast percentages experienced already.

As recommended, when only $1.25 \mathrm{~mm}$ thick bark shaving is removed at each tapping, each panel can be consumed for about 6 years at every other day tapping. Bark consumption rate should be controlled by guidelines marked on the panel every year using a proper stencil.
When the tapping quality is good, the panel above the tapping cut will be smooth and even, with no nodule formation due to damaged cambium.

In order to obtain the potential yields economically, each panel should be exploited for at least 6 years i.e. under every other day tapping generally termed as "d2 tapping". But the average bark consumption rate, according to the data gathered so far is about 4 years per panel. In a situation like this, the crop loss is huge and can be calculated as follows.

When a panel that should be tapped for 6 years is consumed in 4 years, the crop loss on the two virgin panels will be equal to 4 years crop (two years on each panel). If the average yield per hectare is $1000 \mathrm{~kg}$, this is about $4000 \mathrm{~kg}$ of rubber. When two virgin panels are consumed 4 years earlier than the recommended period of 12 years, the renewed panels cannot give expected yields as they are only partially renewed. Further, if the same high frequency is practiced on the 
renewed panels as well, then another 4 years are lost on renewed panels.

Therefore, the total crop loss will be a crop for 8 years and lower crop due to tapping on partially renewed panels. This amount will be equal to about 9000 $\mathrm{kg}$ of rubber and even at a moderate price of Rs.350/=, this will be over 3 million rupees per hectare.

As the high-frequency tapping leads to drying up of trees, the effect will be even higher which has not been taken into consideration for the above calculation. A gradual increase in "brown bast" with the increase of the age of the clearing is acceptable, to be around 5-10\%. But, in clearings where the tapping frequency is very high, the percentage of brown bast affected trees has well exceeded the accepted levels. Therefore, this condition should properly be understood by the management of estates and remedial actions should be taken with no further delay. Many observations on tapping panel dryness with local clones under different conditions have been reported by Seneviratne et al. (2007).

One reason for this situation seems to be the wrong estimates or rather "crop targets" which can never be achieved or realized from present-day clearings that are on estates. Further, the only strategy adopted to achieve the targets is to increase the number of tappings. These extra tappings are called "recovery tappings" which leads to daily tapping of the trees eventually. Recovery tappings are recommended when normal tappings are disturbed due to rain interferences or lack of tappers but with strict guidelines i.e. 2 per week and 6 per month. Under daily tapping conditions, the crop will be reduced gradually. When the crop is low more tappings will be needed to cover the estimates. This will go on and on until the tree becomes dry.

Michels et al. (2012) have reported a similar exercise in which the life span of plantations had been diagnosed using the amount of virgin bark consumed and the number of tapping years that remained. They have validated that in a sample of 25 smallholder plantations in Cameroon, where they have characterized eight tapping management systems reflecting different levels of tapping intensity. The assessment of the respective share of each tapping practice on virgin bark consumption has revealed major effects of tapping frequency and of shaving thickness.

They have used the information gathered through this for decision making which can increase remaining tapping years and as useful support for the participatory development of innovating tapping management schemes involving both technicians and smallholders Lacote, et al. (2013).

Atminingsih and Darojat (2019) have studied the effect of the direction of the cut, panel height, and the frequency of tapping on the shaving thickness of the bark. Tapping frequency effect was investigated in a trial plot using the frequency of once in three days (d3), four days (d4), five days (d5), six days (d6), and eight days (d8) on the basal panel (B0-2). Bark thickness has been measured directly using a digital caliper. They have observed that the frequencies $\mathrm{d} 5, \mathrm{~d} 6$, and $\mathrm{d} 8$ had resulted in insignificantly thicker bark shavings per tapping compared to $\mathrm{d} 3$ and $\mathrm{d} 4$ which 
P Seneviratne et al.

had a lower thickness of bark shaving. The recent trend in rubber exploitations everywhere is adopting a low-frequency tapping system to reduce labor costs consequently to the low rubber price in recent years. They have indicated that though low-tapping frequency applications would increase daily bark shaving thickness, the annual total would be lower due to less tapping days per year.

Their observations and results have also indicated that upward tapping had higher bark shaving thickness than downward tapping. In downward tapping, the lower the tapping position, the higher the shaving thickness would be, whilst in upward tapping, shaving thickness had increased along with the panel height. In this study too a higher bark consumption was observed in the upper-cuts which is anyway unavoidable.

Opening a downward cut above the dry panel is an unsuccessful attempt as the drainage area will soon be over making no crop. If the upper-cut was an upward cut and if not the tree is fully stressed, a reasonable crop could have been obtained from such trees. In the report it was advised to this kind of tapping with immediate effect and upward cuts were introduced most of the time a quarter cut. Atminingsih and Darojat (2019), have classified panel heights into $<50 \mathrm{~cm}, 50$ - $100 \mathrm{~cm}$, and $100-130 \mathrm{~cm}$ in downward tapping and $130-150 \mathrm{~cm}$, $150-170 \mathrm{~cm}$, and $>170 \mathrm{~cm}$ in upward tapping. In downward tapping, the lower tapping position, the higher the bark shaving would be, whilst in upward tapping, bark shaving thickness has increased along with the panel height.
Our observations are on par with their conclusions.

In the present survey, for about $90 \%$ of the fields, the recommendation was to stop harvesting the panel on tapping and to open an upward $1 / 4$ spiral cut on the opposite panel, which is generally termed as CUT or controlled upward tapping. Soon after the visit to the estates for data collection, calculations were done and a report consist of the current issues and the remedial actions to be taken to address the issues were sent to the management of each estate with a copy to the CEO of the RPC, for implementation. The response was very positive and the recommendations were implemented in almost all the cases.

As seen in figure 9 of the results section, a correlation exists between the tapping panel dryness and the excessive bark consumption. But it would be more pronounced if the variables such as location, clone, tapper etc., could be excluded, which was not possible in this exercise.

The damage to the tree due to overexploitation is permanent. Therefore, if this rate continues, the rubber production in the country is severely affected while the rubber industry, in particular, the local consumers compelled to import more and more rubber to the country to maintain the production in their factories. From 2013 onwards, bark auditing was done only on the requests received from estates. Also, the Ready-Reckoner chart developed to read the correct bark position by measuring the current panel position was an important invention (Silva et al., 2012). 
Impact of tapping quality on sustainability of rubber

\section{References}

Anon (2013). Clone Recommendation. Genetics and Plant Breeding Department, Rubber Research Institute of Sri Lanka.

Anon (2016). Tapping and use of Rainguards. 2016/03. Plant Science Department, Rubber Research Institute of Sri Lanka.

Anon (2017). Statistical Pocket Book. Ministry of Plantation Industries.

Atminingsih, J and Darojat, M R (2019). Direction, panel height, and tapping frequency affect the daily bark consumption in Hevea rubber tapping. Planta Tropika: Jurnal Agrosains (Journal of Agro Science) 7, 58-65.

Munasinghe, E S, Rodrigo, V H L and Gunawardena, U A D P (2014). Modus operandi in assessing biomass and carbon in rubber plantations under varying climatic conditions. Experimental Agriculture 50(1), pp.40-58.

Eschbach, J M, Lacrotte, R, Serres, E (1989). Conditions which favor the onset of brown bast. In: d'Auzac J, Jacob JL, Chrestin H (eds). Physiology of Rubber Tree Latex. CRC, Boca Raton, pp.443-454.

Lacote, R, Doumbia, A, Obouayeba, S, and Gohet, E (2013). Tapping panel diagnosis, decision support tool for more sustainable rubber tapping system. IRRDB-MRPPA International Workshop on The Development of Smallholder Rubber Industry in Myanmar. https:// doi.org/10.13140/RG.2.1.3148.7527.

Lacote, R, Obouayeba, S, ClémentDemange, A, Dian, K, Gnagne, $\mathrm{M}$ and Gohet, E (2004). Panel management in rubber (Hevea brasiliensis) tapping and impact on yield, growth, and latex diagnosis. Journal of Rubber Research 7, 199-217.

Michels, T, Eschbach, J M, Lacote, R, Benneveau, A and Papy, F (2012). Tapping panel diagnosis, an innovative on-farm decision support system for rubber tree tapping. Agronomy for Sustainable Development 32 (3), 791-801. https://doi.org/10.1007/s 13593-011-006 9-2.

Michels, T, Eschbach, J M, Lacote, R, Benneveau, A and Papy, F (2012). Tapping panel diagnosis, an innovative on-farm decision support system for rubber tree tapping. Agronomy for Sustainable Development, Springer Verlag/EDP Sciences/ INRA, 32 (3), pp.791-801.

Nugawela, A (2001). Exploitation for economic yields. In: Hand Book of Rubber Vol. Agronomy, pp.176-190. (Eds. L M K Tillekeratne and A Nugawela), Rubber Research Institute of Sri Lanka, Agalawatta

Obouayeba, S, Coulibaly, L F, Gohet, E, Yao, T N and Ake, S (2009). Effect of tapping systems and height of tapping opening on clone PB 235 agronomic parameters and it's susceptibility to tapping panel dryness in south-east of Côte d'Ivoire. Journal of Applied Bioscience 24,1535-1542.

Senevirathna, A M W K, Wilbert, S, Perera, S A P S and Wijesinghe, A K H S (2007). Can tapping panel dryness of rubber (Hevea brasiliensis) be minimized at field level with better management? Journal of the Rubber Research Institute of Sri Lanka 88, 77-87.

Silva, T U K, Seneviratne, P, Amaratunge, K A G B (2012). Development of Ready Reckoner to assess the impact of excessive bark consumption in $\mathrm{S} / 2 \mathrm{~d} 2$ and $\mathrm{S} / 2 \mathrm{~d} 3$ harvesting systems. Journal of the Rubber Research Institute of Sri Lanka 92, 22-31.

Address for correspondence: Dr (Mrs) $\mathrm{P}$ Seneviratne, Deputy Director Research Biology, Rubber Research Institute of Sri Lanka, Dartonfield, Agalawatta, Sri Lanka. e-mail:ddrbiorrisl@gmail.com 